\title{
Norādāmo vietniekvārdu lietojums latviešu un somu presē
}

\section{The usage of demonstrative pronouns in Latvian and Finnish press}

\author{
Emīilija Mežale \\ Latvijas Universitāte, Humanitāro zinātņu fakultāte \\ Visvalža iela 4a, Rīga, LV-1050 \\ E-pasts: emilija.mezale@gmail.com
}

\begin{abstract}
Rakstā aplūkots norādāmo vietniekvārdu lietojums latviešu un somu presē. Uzmanība galvenokārt pievērsta norādāmo vietniekvārdu adjektīviskam lietojumam, tostarp artikula un emocionālās ekspresijas pastiprinātāja nozīmēe, kā arī sniegts ieskats norādāmo vietniekvārdu substantīviskā lietojumā. Raksta pirmajā daḷā aplūkots norādāmo vietniekvārdu substantīvisks lietojums, apskatot gan tādus gadījumus, kad vietniekvārdi norāda uz priekšmetiem, gan tādus sarunvalodai raksturīgus gadījumus, kad tie norāda uz personām. Raksta otrajā dạ̦ā aplūkoti norādāmie vietniekvārdi adjektīviskā lietojumā, pievēršot uzmanību gan lietojumam ar konkrētu referenci tekstā, gan norādāmā artikula funkcijai tuvinātam lietojumam bez konkrētas references tekstā. Aplūkotā teorija ilustrēta ar piemēriem no preses tekstiem. Rezultātā izškikirtas trīs adjektīviski lietotu vietniekvārdu grupas, no kurām divas robežojas ar noteiktā artikula nozīmi. Iegūtie rezultāti tiks izmantoti, lai turpinātu padziḷināti pētīt un analizēt vietniekvārdu lietojumu latviešu un somu valodā.
\end{abstract}

Atslēgvārdi: norādāmie vietniekvārdi; noteiktais artikuls; preses valoda; latviešu valoda; somu valoda.

\section{levads}

Raksta mērķis ir iepaz̄̄stināt ar norādāmo vietniekvārdu lietojumu preses tekstos latviešu un somu valodā, galvenokārt pievēršot uzmanību norādāmo vietniekvārdu adjektīviskam lietojumam, tostarp noteiktajam artikulam tuvinātā funkcijā, kā arī norādāmā vietniekvārda lietojumam, runājot par personām. Lai labāk raksturotu konkrēto parādību izmantojumu presē, rakstā sniegts ieskats arī vietniekvārdu lietojumā latviešu un somu valodā vispār.

Gan latviešu, gan somu valodā ir vairāki norādāmie vietniekvārdi, kuru lietojumu var skatīt gan no situatīiāa, telpiskā un temporālā, gan no diskursa viedokḷa. Kā raksta Daina Nītiņa $(2013,439)$, ,parasti tiek uzsvērta norādāmo vietniekvārdu opozīcija telpiskā izvietojuma vai laika raksturošanā, proti, tas, ka vietniekvārds šis, šs norāda uz tuvākām, bet tas, tāa - uz tālākām dzīiām būtnēm un priekšmetiem vai attiecīgi uz tuvāku un tālāku laiku”, turklāt „,bieži ar šis, šç tiek norādīts tieši uz pašreizējo laiku, pašreizējiem notikumiem, uz noteiktā situācijā (vai šim brīdim) svarīgāko, aktuālāko". Opozīciju dalījums telpiskā izvietojuma raksturošanā lielākoties parādās tieši tajos gadījumos, ,ja vēlas diferencēti rādīt priekšmetu izvietojumu, ja uzmanības centrā ir tas, kurš no objektiem atrodas tuvāk, kurš tālāk [..]” (Nītiņa 2013, 439). Andra Kalnača $(2013,70)$ piemin arī 
norādāmo vietniekvārdu viņš, vin,a, kas norāda uz l,oti tāliem objektiem vai to pazīmēm, tomēr vienlaikus raksta, ka šis vietniekvārds ,,mūsdienu latviešu valodā vairāk sastopams daiḷliteratūrā, retāk plašsaziņas līdzekḷu tekstos, lietišķos vai zinātniskos tekstos". Raksta autore aplūkotajos preses tekstos nav atradusi nevienu gadījumu, kurā viņš, viņa tiktu lietots kā norādāmais vietniekvārds.

Arī somu valodā tiek lietoti dažādi norādāmie vietniekvārdi, norādot uz priekšmetiem vai būtnēm, kas tieši novērojamas runas aktā vai pieminētas tekstā (Hakulinen et al. 2004, §7201). Interesanta ir nianse, ka ,vietniekvārds tämä 'šis' norāda uz priekšmetu, kas atrodas runātāja uzmanības lokā, vietniekvārds se 'tas' - uz priekšmetu, kas atrodas adresāta uzmanības lokā, savukārt vieniekvārds tuo 'tas tur' var norādīt uz priekšmetu gan runātāja, gan adresāta uzmanības lokā” (Hakulinen et al. 2004, §720). Šādā norādāmo vietniekvārdu vērtējumā uzmanība tiek pievērsta ne tikai telpiskā vai temporālā izvietojuma opozīcijai, bet arī aktualitātei diskursā attiecībā pret runātāju un klausītāju. Jāpiebilst, ka šāds lietojums var būt atkarīgs ne tikai no runātāja un adresāta uztveres, bet arī no konteksta.

Norādāmo vietniekvārdu lietojums, norādot uz runātājam vai adresātam aktuālo, cieši sasaucas ar norādāmo vietniekvārdu lomu teksta tēmas aktualizācijā latviešu valodā rakstītos tekstos , vietniekvārdi šis, š $\bar{l}, t a s, t \bar{a}$ (arī $̌ \bar{s} d s, \check{s} \bar{a} d a, t \bar{a} d s$, tāda) l̦oti plaši tiek lietoti, arī norādot uz tekstā iepriekš minētu vai sekojošu informāciju” (Kalnača 2013, 70), bet somu valodā ,tämä 'šis, šî’ un tuo 'tas tur, tā tur' norāda uz tēmu, kas no klausītāja (vai lasītāja) viedokḷa ir jauna, bet se 'tas, tā' - uz tēmu, kas klausītājam ir jau pazīstama” (Larjavaara 2001b). To var papildināt ar „Iso suomen kielioppi” („Lielā somu valodas gramatika”) minēto, ka „,tämä 'šis, šî̀' norāda, ka tiek aplūkota jauna reference vai jau zināmas references jauns aspekts, savukārt tuo 'tas tur, tā tur' [..] norāda uz referenci, kas konkrētajā runas situācijā nav galvenā” (Hakulinen et al. 2004, §1413). Iespējams, to var saistīt ar raksta autores novērojumu, ka tieši tämä 'šis, šì un tuo 'tas tur, tā tur' visbiežāk tiek lietoti, atsaucoties uz tekstā iepriekš minēto informāciju, to vēlreiz atkārtojot un aktualizējot, kamēr se 'tas, tā' visbiežāk tiek lietots noteiktā artikula funkcijā, proti, bez konkrētas references - tas sīkāk aplūkots raksta 1. un 2. daḷā.

Analizējot norādāmo vietniekvārdu lietojumu latviešu un somu presē un ņemot vērā iepriekš aplūkotos norādāmo vietniekvārdu nozīmju aspektus, autore ir novērojusi, ka norādāmajiem vietniekvārdiem preses tekstos parādās vairākas funkcijas, proti, iespējams atrast paraugus lielākajai daḷai minēto lietojumu. Dažas no norādāmo vietniekvārdu funkcijām preses tekstos atbilst to pamatfunkcijām, kamēr citas ir uzskatāmas par sarunvalodiskām.

1 Šeit un turpmāk izmantota "Lielās somu valodas gramatikas” elektroniskā versija (Hakulinen, Auli et al. 2004. Ison suomen kieliopin verkkoversio. Helsinki: Suomalaisen Kirjallisuuden Seura), kas pieejama tīmekḷa lapā http://scripta.kotus.fi/visk/sisallys. $\mathrm{php}$ ? $\mathrm{p}=15$. Gramatikas elektroniskajā versijā lappuses nav numurētas, tādēl atsaucēs norādīti paragrāfi. 
Novērotas divas galvenās funkcijas ar apakšfunkcijām.

1. Norādāmo vietniekvārdu substantīvisks lietojums:

1.1 norādāmo vietniekvārdu substantīivisks lietojums, norādot uz priekšmetu;

1.2 norādāmo vietniekvārdu substantīvisks lietojums, norādot uz personu.

2. Norādāmo vietniekvārdu adjektīvisks lietojums:

2.1 norādāmo vietniekvārdu adjektīvisks lietojums ar konkrētu referenci;

2.2.a norādāmo vietniekvārdu adjektīvisks lietojums bez konkrētas references jeb lietojums noteiktā artikula funkcijā;

2.2.b norādāmo vietniekvārdu lietojums emocionālā pastiprinātāja nozīmē.

Tālāk rakstā tiks aplūkotas katras norādāmo vietniekvārdu lietojuma funkcijas iezīmes, kā arī analizēti konkrēti piemēri no preses tekstiem. Valodas materiāls ņemts no četriem tiešsaistes preses izdevumiem latviešu un somu valodā (sk. avotus). Kopumā apskatīts ap 200 vienību.

Daḷa piemēru ar norādāmajiem vietniekvārdiem adjektīva funkcijā bez konkrētas references (sk. raksta 2.2. daļu) jau skatīti Emīlijas Mežales (2018) rakstā „Norādāmie vietniekvārdi noteiktā artikula funkcijā latviešu un somu preses tiešsaistes izdevumos: pragmatiskā pieeja", taču to analīze paturēta arī šeit, jo tādu piemēru līdz šim skatītajos preses tekstos atrasts maz un autorei šķiet lietderīgi šajā rakstā ilustrēt visus norādāmā vietniekvārda lietojuma variantus.

\section{Norādāmo vietniekvārdu substantīvisks lietojums}

\subsection{Norādāmo vietniekvārdu substantīvisks lietojums, norādot uz priekšmetu}

Norādāmo vietniekvārdu substantīvisks lietojums ir viena no to pamatfunkcijām. Substantīviskā lietojumā norādāmie vietniekvārdi var gan norādīt uz priekšmetiem un dz̄ivām būtnēm, gan tikt lietoti ,substantīvu vietā, kas nosauc gan dz̄ivas būtnes, gan priekšmetus" (Paegle 2003, 18). Gadījumos, kad norādāmie vietniekvārdi lietoti substantīvu vietā, tie aizstāj tekstā iepriekš minētu vārdu, vārdkopu vai teikuma daḷu (šādā gadījumā aizstātais vārds un norādāmais vietniekvārds nereti atrodas vienā teikumā), vai arī veselu teikumu vai garāku teksta fragmentu (šādā gadījumā aizstātais teksts nereti jāmeklē plašākā kontekstā).

Kā norāda D. Nītina (2013, 440-441), ,vispārinātā norādītājvārda funkcijā parasti lieto vietniekvārdu tas, tā [..], un šis vietniekvārds latviešu valodā ir biežāk sastopams nekā šis, š̄ vārdformas”, turklāt ,vispārinātā nozīmē vietniekvārds tas, tā parasti tiek lietots substantīviski”. Tādējādi secināms, ka norādāmā vietniekvārda substantīvisks lietojums uzskatāms tieši par vietniekvārda tas, tā pamatlietojumu. Somu valodā savukārt šāds dalījums nepastāv, proti, literatūrā nav atrodama informācija par to, ka kāds no vietniekvārdiem tiktu pamatā lietots substantīva funkcijā, bet kāds cits - adjektīva funkcijā. Tas, iespējams, saistīts ar to, ka somu valodā liela nozīme ir norādāmo vietniekvārdu telpisko pozīciju dalījumam (sk., piem., Larjavaara 2001b) - līdz ar to arī substantīviskā lietojumā ir 
svarīgi tas, kādā telpiskā pozīcijā no runātāja vai adresāta atrodas ar vietniekvārdu aizstātais priekšmets. No telpiskajām pozīcijām nereti izriet arī references tekstā.

Tā kā norādāmo vietniekvārdu substantīvisks lietojums ir viena no to pamatfunkcijām, tas ir bieži sastopams preses tekstos, kad, tā vietā lai vārdu atkārtotu, tas tālākā tekstā tiek aizstāts ar vietniekvārdu. Šāds norādāmo vietniekvārdu lietojums, norādot uz priekšmetu, ir neitrāls un nav uzskatāms par sarunvalodisku. Kā ilustrē piemēri (1)-(3), šādā lietojumā lielākoties parādās tieši vietniekvārds tas, kas sasaucas ar teorijā rakstīto.

Piemērā (1) vietniekvārds tas tiek lietots lietvārda narkotikas vietā, tādējādi izvairoties no vārda atkārtošanas. Tā kā norādāmais vietniekvārds un lietvārds tekstā atrodas tuvu viens otram, nav nekādu šaubu par to, kurš tieši vārds tiek aizstāts, turklāt, lietojot vietniekvārdu, teksta autors var izvairīties no stilistiski neveiksmīga vārdu atkārtojuma.

(1) Baložu iecirkn̄̄ šonedēl saņemta informācija par vairākām personām, pie kurām, iespējams, atrodas narkotikas un kuras, iespējams, tās pārvadā ar mikroautobusu. (www.diena.lv)

Piemērā (2) ar norādāmo vietniekvārdu tas tiek aizstāta teikuma pirmā daḷa pasaules kausa posms izdevās. Arī šajā gadījumā vietniekvārda lietojums nerada neskaidrības un pat varētu būt uzskatāms par neizbēgamu.

(2) Pasaules kausa posms izdevās, un to arī atzinīgi novērtēja Starptautiskāa federācija. (www.diena.lv)

Piemērā (3), skatot teikumu atrauti no konteksta, nav saprotams, ko tieši aizstāj norādāmais vietniekvārds tas. Šajā gadījumā ar to tiek norādīts uz tekstā iepriekš aplūkotu tēmu, kas jāmeklē plašākā kontekstā. Tikai lasot visu rakstu, ir skaidrs, ka runa ir par ASV Senāta pieņemto likumu, kas sekmēs tuvāku attiecību veidošanu ar Taivānu. Šajā gadījumā norāde uz konkrēto likumu meklējama raksta apakšvirsrakstā, savukārt piemērā (3) aplūkotais teikums - divas rindkopas tālāk. Piemērs labi ilustrē to, ka norādāmais vietniekvārds substantīviskā funkcijā ne vienmēr tiek lietots, lai aizstātu vārdu tā paša teikuma vai pat rindkopas ietvaros, tādēl ir ḷoti svarīgi zināt kontekstu, lai saprastu tāda teikuma jēgu, kāds aplūkots piemērā (3).

(3) Lai tas stātos spēkā, tam nepieciešams tikai ASV prezidenta Donalda Trampa paraksts. (www.diena.lv)

Arī somu valodā norādāmo vietniekvārdu substantīvisks lietojums ir parasts un atbilst literārās valodas normām. Piemērā (4) ar vietniekvārdu se 'tas, tā' otrajā teikuma daḷā aizstāta pirmajā teikuma daḷā minētā abreviatūra SMA (no angḷu val. spinal muscular atrophy 'spinālā muskuḷu atrofija'), savukārt piemērā (5) - vārds kunnianosoitus 'pagodinājums'.

$\begin{array}{lllll}\text { Silloin, } & \text { kun } & \underline{\text { SMA }} & \text { alkaa } & \text { aikuisiässä, } \\ \text { tad } & \text { kad } & \text { SMA.NOM } & \text { sākties.PRS.3 } & \text { pieaugušā vecums.INES } \\ \text { se } & \text { on } & & \begin{array}{l}\text { huomattavasti } \\ \text { hitaammin }\end{array} \\ \text { tas.NOM } & \text { būt.AUX.PRS.3 } & \text { ievērojami } & \text { lēnāk }\end{array}$


etenevä.

attīstīties.PTCP.ACT.PRS

'Tad, ja SMA parādās pieaugušā vecumā, tā attīstās krietni lēnāk.' (www.yle.fi) $)^{2}$

(5)

$\begin{array}{lllll}\text { Seuri } & \text { pitää } & \text { kunnianosoitusta } & \text { tärkeänä, } & \\ \text { Seuri.NOM } & \text { turēt.PRS.3 } & \text { pagodinājums.PART } & \text { svarīgs.ESS } & \\ \text { sillä } & \text { se } & \text { tulee } & \text { hänen } & \text { omalta } \\ \text { jo } & \text { tas.NOM } & \text { nākt.PRS.3 } & \text { viņš.GEN } & \text { pats.ABL } \\ \text { ammatilliselta } & \text { yhteisöltään. } & & \\ \text { amata-.ABL } & \text { kopiena.ABL } & & \end{array}$

'Seuri pagodinājums ir svarīgs, jo tas nāk no paša amatbrāḷiem.'

(www.yle.fi)

Piemērs (6) savukārt atbilst piemēram (3), proti, lai saprastu, kas ir aizstāts ar vietniekvārdu se 'tas, tā', nepieciešams zināt plašāku kontekstu - šajā gadījumā nav atrodams konkrēts teikums vai frāze, kas būtu aizstāts, tomēr piemērā minētās izmeklēšanas saturs noprotams no iepriekšējā teksta. Papildinformāciju sniedz arī piemērā redzamais palīgteikums joka on aiemmin keskittynyt Venäjän rooliin Yhdysvaltain presidentinvaaleissa vuonna 2016 'kurā līdz šim uzmanība pievērsta Krievijas lomai ASV prezidenta vēlēšanās 2016. gadā', no kā var izsecināt tēmu, arī neredzot pārējo tekstu.

(6) Se

tas.NOM

on

būt.AUX.PRS.3

Venäjän

Krievija.GEN

vuonna

gads.IRR ESS tarkoittaa, nozīmēt.PRS.3 aiemmin

agrāk rooliin loma.ILL 2016, on

$$
\text { että }
$$
tutkinta, joka ka izmeklēšana.NOM kura.NOM

'Tas nozīmē, ka izmeklēšana, kurā līdz šim uzmanība pievērsta Krievijas lomai ASV prezidenta vēlēšanās 2016. gadā, ir paplašinājusies [..].' (www.hs.fi)

Kā redzams aplūkotajos piemēros, norādāmā vietniekvārda lietojums substantīva funkcijā, norādot uz iepriekš minētu priekšmetu vai tēmu, tekstam nepiešķir nekādu sarunvalodisku ekspresiju, tas uzskatāms par neitrālu un atbilst vietniekvārda pamatfunkcijai. Interesanti - lai arī somu valodā nav norāžu par to, ka kāds no vietniekvārdiem šajā funkcijā tiktu lietots vairāk nekā citi, piemēros tomēr dominē vietniekvārds se 'tas, tā'. Tādējādi varētu secināt, ka tas somu valodā uzskatāms par neitrālu vietniekvārdu un ne vienmēr saistāms ar telpisku pozīciju dalījumu.

\footnotetext{
2 Šeit un turpmāk piemērus no somu valodas tulkojusi raksta autore.
} 


\subsection{Norādāmo vietniekvārdu substantīvisks lietojums, norādot uz personu}

Somu sarunvalodā ir izplatīts norādāmo vietniekvārdu tämä ‘šis, šs’', tuo 'tas tur, tā tur' un se 'tas, tā’ lietojums, runājot par personām (Tiittula, Nuolijärvi 2013, 76), turklāt somu sarunvalodā šāds lietojums uzskatāms par neitrālu lietojumu bez negatīvas ekspresijas (Hakulinen et al. 2004, §720; Tiittula, Nuolijärvi 2013, 61). Arī Hanna Lapalainena (Hanna Lappalainen 2010) norāda, ka lietišksā tekstā, runājot par personām, tiek izmantots trešās personas vietniekvārds hän 'vinuš, viņa', taču ikdienas sarunvalodā priekšroka tiek dota norādāmajiem vietniekvārdiem. H. Lapalainena (2010) turklāt akcentē - lai arī literārajā valodā ir ieviesta norma, ka uz cilvēku trešajā personā norāda ar vietniekvārdu hän 'viņš, viņa', bet uz dż̄vniekiem, priekšmetiem u.c. ar norādāmo vietniekvārdu se 'tas, tā', tā nekad nav bijusi spēkā, piem., izloksnēs un dialektos, kur abos gadījumos nešķirojot izmantots gan personas, gan norādāmais vietniekvārds. Turklāt daudzās izloksnēs tieši norādāmā vietniekvārda se 'tas, tā' lietojums atzīstams par neitrālu, kamēr personas vietniekvārda hän 'viņš, viņa' lietojums - par izṇēmumu. Šāda norādāmā vietniekvārda lietojuma ekspresivitāte tomēr nenoliedzami ir kontekstuāla, un, ja lietojums parādās rakstītā tekstā, l,oti iespējams, ka tam tomēr tiek piešķirta papildu konotācija.

Šādā lietojumā škirir dažādu vietniekvārdu nozīmes, proti, mutvārdu sazin̄ā tämä 'šis, šì', tuo 'tas tur, tā tur' var norādīt uz personām, kas piedalās runas aktā, bet vienlaikus gan mutvārdu, gan rakstveida saziņā tämä 'šis, šî̀' var arī norādīt uz tekstā nupat pieminētu personu (Hakulinen et al. 2004, §720).

Latviešu valodā šādi lielākoties lietots norādāmais vietniekvārds šis, š̄ , un tas, ,norādot uz personu, izsaka nievājuma nokrāsu” (Paegle 2003, 81). D. Nìtiņa (2013, 441) savukārt papildina, rakstot, ka ,sarunvalodā vai tās atainojumā daiḷdarbos substantīvisks vietniekvārds tiek izmantots, gan runājot par tuviniekiem vai pazin̄ām, gan izsakot neticību kaut kam vai humoristisku attieksmi, arī negatīvu, pat nievājošu vērtējumu", proti, nievājuma nokrāsa ir tikai viena no iespējamām papildnozīmēm, ko tekstā sniedz norādāmā vietniekvārda lietojums, runājot par personu.

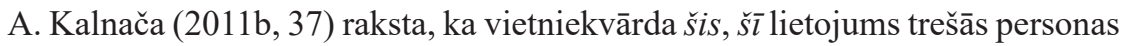
vietniekvārda funkcijā visbiežāk parādās interneta komentāros, savukārt citos plašsaziņas tekstos tas parasti netiek šādi lietots. To ir novērojusi arī raksta autore, kurai līdz šim analizētajos tekstos ir izdevies atrast tikai vienu pārliecinošu piemēru ar norādāmā vietniekvārda lietojumu trešās personas vietniekvārda funkcijā, turklāt - somu valodā. Piemērs ir no sporta ziņu teksta, kas ir likumsakarīgi, jo sporta ziņās nereti parādās sarunvalodiski runāta teksta citējumi, pat ja tās nav intervijas:

$\begin{array}{lllll}\text { Pärmäkoski } & \text { pysyi } & \text { hyvin } & \text { Björgenin } & \text { vauhdissa } \\ \text { Permekoski.NOM } & \text { palikt.PST.3 } & \text { labi } & \text { Bjergena.GEN } & \text { àtrums.INES } \\ \text { mukana, } & \text { kun } & \text { tämä } & \text { kiristi } & \text { tahtia } \\ \text { līdzi } & \text { kad } & \text { šī.NOM paātrināt.PST.3 } & \text { temps.PART } \\ \text { matkan } & \text { puolivälin } & \text { Murhamäessä } & \\ \text { distance.GEN } & \text { pusceḷ̆š.GEN } & \text { Murhameki.INES } & \end{array}$


'Permekoski labi turējās līdzi Bjergenai, kad šĩ distances vidū, Murhameki, paātrināja tempu.' (www.yle.fi)

Piemērā (7) ar norādāmo vietniekvārdu tämä 'š̄is, šs̄' aizstāts sportistes uzvārds Björgen 'Bjergena'. Kontekstā ir skaidrs, ka šeit norādāmā vietniekvārda substantīvisks lietojums, norādot uz personu, ir neitrāls, tekstā neparādās nekāda veida negatīva konotācija. Tomēr, kā jau minēts, aplūkotajos avotos šādu piemēru gandrīz nav, tādēḷ par norādāmā vietniekvārda lietojumu trešās personas vietniekvārda funkcijā somu un latviešu tiešsaistes preses tekstos kopumā pagaidām iespējams izdarīt tikai vienu secinājumu: šāds lietojums tajos neparādās. Lai nonāktu pie citiem secinājumiem, risinājums varētu būt aplūkojamo teksta žanru klāsta paplašināšana, iekḷaujot analīzē arī preses tekstu komentārus.

\section{Norādāmo vietniekvārdu adjektīvisks lietojums}

Ar̄̄ norādāmā vietniekvārda lietojums adjektīva funkcijā jeb blakus apzīmējamam vārdam ir viena no vietniekvārdu pamatfunkcijām. Šādi lietots, vietniekvārds šis, šs pievērš kaut kam uzmanību, saasinot un koncentrējot uzmanību „uz kaut ko vienu pārējo lietu, parādību vidū” un uzsverot vai nodalot to no kaut kā cita (Nītiņa 2013, 440). Būdams atribūts, norādāmais vietniekvārds „tiek lietots kopā ar apzīmējamo vārdu” (Nītiņa 2013, 440), proti, tas tiek novietots pozīcijā pirms lietvārda un to neaizstāj, kā tas ir substantīviska lietojuma gadījumā. D. Nītiņa $(2013,441)$ turklāt pievērš uzmanību tam, ka adjektīvisks lietojums jeb saistījums ar kādu lietvārdu ir raksturīgs tieši vietniekvārdam šis, š̄ , savukārt, kā norāda A. Kalnača $(2013,70)$, noteiktā artikula funkcija sarunvalodā un plašsaziṇas līdzekḷu tekstos visbiežāk sastopama vietniekvārdam tas, tā, retāk šis, šč. Arī somu valodā norādāmajiem vietniekvārdiem sastopams adjektīvisks lietojums (Hakulinen et al. 2004, §720, §1413). Rakstītā tekstā šādi lietots norādāmais vietniekvārds parasti norāda uz kaut ko tekstā iepriekš pieminētu vai arī uz pašu tekstu kā veselumu (Hakulinen et al. 2004, §722).

Kā viens no norādāmo vietniekvārdu lietojuma veidiem adjektīva funkcijā noteikti jāmin norādāmais vietniekvārds kā emocionālās ekspresijas pastiprinātājs. Tieši šajā lietojumā adjektīviski lietots norādāmais vietniekvārds norāda uz tēmas svarīgumu un emocionālo papildinformāciju. Lai arī formāli norādāmo vietniekvārdu lietojums emocionālās ekspresijas pastiprinātāja funkcijā ir grūti nošķirams no norādāmajiem vietniekvārdiem tīrā artikula funkcijā, kas ir raisījis neviennozīmīgu abu parādību vērtējumu (Kalnača 2011a, 110; Ozola 2006, 85), tas gan lietojumā, gan līdzšinējā vērtējumā atškiras no artikula funkcijas. Tas ir mudinājis raksta autori pievērst šim jautājumam pastiprinātu uzmanību un meklēt iespējamas pazīmes, pēc kurām abus lietojumus varētu nošķirt. Par to sīkāk sk. 2.2. nodaḷā.

Norādāmais vietniekvārds adjektīviskā lietojumā nereti tiek lietots arī noteiktā artikula nozīmē, lai gan ne latviešu, ne somu valodas gramatiskajā sistēmā artikulu kategorijas nav (Hakulinen et al. 2004, §569; Ozola 2006, 84-85; Kalnača 2011a, 108-109; Kalnača 2011b 33-35; Nītiņa 2013, 440-441; Tiittula, Nuolijärvi 2013, 82). Šādā lietojumā vietniekvārdiem zūd to parastā funkcija, proti, atsaukties uz kādu tekstā iepriekš minētu parādību, priekšmetu vai būtni (Hakulinen et al. 
2004, §569, §1413; Nītina 2013, 429). Darbe Narajana Šankara Bhats (Darbhe Narayana Shankara Bhat 2004, 203-204) gan raksta, ka, piem., angḷu valodā iepriekš minēta priekšmeta vai parādības konkretizēšana, uz to atsaucoties atkārtoti, ir viens no artikulu lietošanas nosacījumiem, tomēr, kā aplūkots tālāk šajā pētījumā, latviešu un somu valodā šādi lietojuma gadījumi ir uzskatāmi par norādāmā vietniekvārda adjektīvisku lietojumu ar noteiktu referenci, kas izriet no tā pamatfunkcijas. Šādā gadījumā nevar runāt par norādāmo vietniekvārdu artikula nozīmē.

Lai spētu novērtēt norādāmo vietniekvārdu lietojumu noteiktā artikula funkcijā preses tekstos, vispirms jāiepazīstas ar noteiktajiem artikuliem, to attīstību, kā arī noteiktības jēdzienu un norādāmo vietniekvārdu vietu tajā.

Tajās valodās, kuru gramatiskajā sistēmā pastāv noteiktais artikuls, kā angḷu, vācu u.c., tas gramatizācijas procesā ir lielākoties attīstījies no norādāmajiem vietniekvārdiem, tiem zaudējot savas leksiskās funkcijas, savukārt nenoteiktais artikuls - no skaița vārda viens (Heine, Kuteva 2004, 8-9, 109-111, 220-221). Lai norādāmais vietniekvārds attīstītos par noteikto artikulu, tam vispirms jāzaudē deiktiskums un norādāmības pazīme - tādējādi tas kḷūst par deiktiski nemarḳētu norādītāju, kas savukārt attīstās par artikulu (Lyons 1999, 331-332). Kā atzīmē Bernds Heine (Bernd Heine) un Tanja Kuteva (Tania Kuteva) (Heine, Kuteva 2004, 110), norādāmais vietniekvārds šajā procesā zaudē telpisko referenci un iegūst tekstuālu jeb diskursa referenci.

Turklāt lielā daļā indoeiropiešu valodu noteiktais artikuls vēsturiski ir attīstījies pirms nenoteiktā artikula. Šis gramatizācijas process valodās ir noticis neatkarīgi, taču tā attīstība ir līdzīga (Crisma 2011, 175). Šādu attīstību varētu skaidrot tā, ka valodās, kurās tiek lietots noteiktais artikuls, vārds vai vārdu salikums kḷūst noteikts tikai tad, ja tas tiek īpaši marḳēts (Crisma 2011, 177). Kā norāda Kristofers Laionss (Christopher Lyons 1999, 33-34), lietvārda frāze (NP, noun phrase) ir uzskatāma par nenoteiktu visos gadījumos, kad tā nav marķēta ar noteikto artikulu vai citu noteiktības norādītāju (definite determiner), pat ja netiek lietots arī nenoteiktības norādītājs, un, piem., lietvārdi daudzskaitlī, ja tie lietoti bez norādītāja, tiek uztverti kā nenoteikti. Tomēr šis likums nav attiecināms uz valodām, kurās noteiktie artikuli nepastāv kā gramatiskās sistēmas daḷa, tostarp latviešu un somu valodu, kurās ir citi paṇēmieni noteiktības izteikšanai, kā vārdu secības maiņa teikumā, īpašības vārdu noteikto galotņu lietojums u.c.

Tāds semantiskās sistēmas pretstats kā noteiktības un nenoteiktības nojēgumi tuvina vietniekvārdus artikula kategorijai (Nītiņa 2013, 431). Tie ir cieši saistīti ar kontekstu, ko norāda arī Ieva Breņķe (2013, 17), rakstot, ka „noteiktības/nenoteiktības kategorijas izpausmē būtiska loma ir kontekstam ne tikai tajās valodās, kurās nav artikulu noteiktības/nenoteiktības izteikšanai [..], bet arī tajās valodās, kurās noteiktību/nenoteiktību izsaka ar noteikto vai nenoteikto artikulu palīdzību [..]". Arī Endrū Čestermens (Andrew Chesterman 1991, 159), kurš ir pievērsies noteiktības kategorijai somu valodā, min, ka tā var tikt izteikta ar noteiktības norādītājiem, taču parasti tiek secināta kontekstā. Līdzekḷi, ar kuriem somu valodā tiek izteikta noteiktība un nenoteiktība, izsaka arī citas nozīmes, kas pārklājas. Piem., partitīva locījums var izteikt nenoteiktu daudzumu un līdz ar to var tikt izmantots kā nenoteiktības norādītājs, taču tam ir arī citas funkcijas. Arī 
vārdu secība teikumā, pirmkārt, palīdz izteikt tēmas aktualitāti un informācijas struktūru, taču nereti var kalpot arī noteiktības vai nenoteiktības izteikšanai, savukārt nenoteikto īpašības vārdu, norādāmo vietniekvārdu un skaitḷa vārdu (ne) noteiktības izteikšanas funkcija ir atvasināta no to pamatnozīmēm.

Latviešu valodā līdzekḷi noteiktības un nenoteiktības kategorijas izteikšanai, kā norāda I. Breņķe (2013, 15-16), „var pārstāvēt visus valodas līmeņus, piem., fonētikā - uzsvara lietojums un intonācija; leksikā - noteikto, nenoteikto, norādāmo, piederības vietniekvārdu izmantojums; morfoloǵijā - noteikto un nenoteikto artikulu lietojums, ǵenitīva un akuzatīva locījuma pretstatījums, veida aspekta izmantojums, lietvārda skaitḷa izmantojums, īpašības vārdu salīdzināmo pakāpju lietojums, noteikto/nenoteikto galotņu opozīcija; sintaksē - konteksts un situācija, vārdu secība, tēmas un rēmas aktuālais dalījums, subjekta un objekta konstrukcija teikumā". Viens no svarīgākajiem līdzekḷiem latviešu valodā ir tieši noteikto un nenoteikto galotņu lietojums, ko ietekmē citi valodas līdzekḷi (Breņķe 2013, 22). Kā norāda Vilma Kalme un Gunta Smiltniece (2001, 133), ,,̄pašỉbas vārda divu veidu galotnēm ir ne vien gramatiska, bet arī semantiska funkcija. Noteiktības kategorija rāda, vai ar lietvārdu nosauktā būtne, parādība vai priekšmets, kuru raksturo īpašības vārds, ir nezināms, nepazīstams, nenoteikts vai zināms, pazīstams, noteikts".

Pēc raksta autores domām, tieši dažādie noteiktības un nenoteiktības izteikšanas paņēmieni ir viens no aspektiem, kādēl latviešu un somu valodā nereti ir atšksirīga attieksme pret norādāmo vietniekvārdu lietojumu noteiktā artikula funkcijā.

Latviešu valodā norādāmais vietniekvārds šis, š̄ , tāpat kā tas, tā, lietots gan adjektīviski, gan subjektīviski, sākot jau ar 16. gs., turklāt adjektīviskajā lietojumā lielas izmaiņas nav vērojamas (Barbare 2002, 340-344). Labi izsekot norādāmā vietniekvārda tas, tā lietojumam noteiktā artikula funkcijā var Artura Ozola monogrāfijā „Veclatviešu rakstu valoda”. Kā min A. Ozols (1965, 92), norādāmā vietniekvārda tas, tā lietošana noteiktā artikula nozīmē, kā arī skaitleṇa viens, viena lietošana nenoteiktā artikula nozīmē parādās jau 16. gs. otrās puses grāmatās un pat 19. gadsimta tekstos vēl joprojām atrodamas norādes par latviešu valodā lietotu artikulu (Ozols 1965, 549). Latviešu valodā tieši vācu valodas ietekmes dēḷ ilgstoši nav bijis skaidrības par artikula šķiršanu no norādāmajiem vietniekvārdiem.

Somu valodā ir mazāk vienprātības par noteiktā artikula pastāvēšanu valodas sistēmā. Ritva Lorija (Ritva Laury 1997, 250) pārstāv viedokli, ka somu valodā artikuli jau pastāv - vismaz to attīstības sākuma stadijā. Kā argumentu savai nostājai R. Lorija (1997, 255-256) min faktu, ka sarunvalodā norādāmais vietniekvārds jau tiek lietots artikula funkcijā un ka ir situācijas, kurās, to izlaižot, mainītos teiktā jēga. Tomēr jāmin, ka R. Lorija (1997, 255) nav konsekventi šķīrusi norādāmā vietniekvārda lietojumu adjektīva funkcijā gadījumā, ja tas piešksir konkrētu referenci un ir saistīts ar iepriekšējo diskursu, no norādāmā vietniekvārda lietojuma artikula funkcijā. Šāds dalījums tomēr ir nepieciešams un ietekmē spriedumu par noteiktā artikula iespējamo pastāvēšanu gramatiskajā sistēmā valodās, kurās tradicionāli nav artikulu. R. Lorija $(1997,260)$ arī norāda, ka somu se mūsdienās var tikt lietots gandrīz visos kontekstos, kuros tiek lietots noteiktais artikuls, izṇemot, šķiet, vienīgi gadījumus, ja vārds apzīmē unikālu 
priekšmetu, tomēr raksta autore uzskata, ka tas nav pietiekams arguments, lai apgalvotu, ka visi šāda lietojuma gadījumi ir gramatiski un tātad būtu iekḷaujami valodas gramatiskajā sistēmā. R. Lorija $(1997,260)$ gan piemin, ka visbiežākais norādāmo vietniekvārdu lietojums artikula funkcijā novērojams Helsinku slengā, kas tikai pastiprina raksta autores nostāju, ka šāds vietniekvārdu lietojums varētu tikt uzskatāms par sarunvalodas normu, tomēr nav uzskatāms par literārās valodas normu.

E. Čestermens (Andrew Chesterman 1991, 152-153) savukārt uzsver, ka norādāmais vietniekvārds se 'tas, tā' un skaitḷa vārds $y k s i$ 'viens' tiek lietoti artikulu nozīmē tieši neformālā runā, ne somu valodā vispār. Viņš pārstāv viedokli, ka somu valodas norādāmie vietniekvārdi vēl nav attīstījušies par noteiktajiem artikuliem, pirmkārt, tādēḷ, ka to lietojums artikulu funkcijā nekādā gadījumā nav vienmēr uzskatāms par obligātu, un, otrkārt, tādēl, ka noteiktības izteikšana nav izveidojusies par to primāro funkciju - norādāmo vietniekvārdu vispārīgā funkcija joprojām ir deiktiska (Chesterman 1991, 153).

Pēc Mati Larjavāras domām (Matti Larjavaara 2001a), somu sarunvalodā norādāmais vietniekvārds adjektīviskā lietojumā varētu tikt uzskatāms par artikulam līdzīgu, taču viņš visai kategoriski iebilst pret domu, ka artikuls kā kategorija jau pastāvētu somu gramatiskajā sistēmā. Kā vienu no argumentiem viņš min to, ka, tulkojot tekstu no kādas valodas, kuras gramatiskajā sistēmā pastāv artikuli, valodā, kurā artikuli nepastāv, tulkojumā artikulus nereti var aizstāt ar vietniekvārdiem, taču bieži tas nav iespējams, jo mērķvalodas kontekstā norādāmais vietniekvārds šādā lietojumā nav derīgs.

Raksta autore pievienojas uzskatam, ka ne latviešu, ne somu valodā norādāmais artikuls joprojām nav uzskatāms par valodas gramatiskās sistēmas daļu, jo tā funkcijā lietotie norādāmie vietniekvārdi pamatā tiek izmantoti citos kontekstos, turklāt saglabājot savu pamatnozīmi. Adjektīviski lietoti norādāmie vietniekvārdi bez konkrētas references jeb artikula funkcijā lietoti norādāmie vietniekvārdi uzskatāmi par sarunvalodisku pazīmi. Ja norādāmais vietniekvārds lietots adjektīviski ar konkrētu referenci, tam nav sarunvalodiskas ekspresijas. Vienlaikus var piekrist, ka sarunvalodiskais norādāmo vietniekvārdu lietojums artikula funkcijā reizēm var padarīt dabīgākas, piem., intervijas, un tādos tekstos norādāmie vietniekvārdi artikulu funkcijā ir piel̦aujami, kā to norādījusi arī A. Kalnača (2011b, 36). Tāpat šāds lietojums varētu būt derīgs emuāru ierakstos un viedokḷu rakstos, lai padarītu tekstu saistošāku. Tomēr arī šī sarunvalodas līdzekḷa lietojums nenoliedzami ir jāvērtē kontekstā.

Norādāmā vietniekvārda adjektīvisks lietojums tā pamatfunkcijā bieži vien ir grūti nošķirams no artikula nozīmes. Lai spētu šķirt abas nozīmes, nepieciešams izprast, kādas pazīmes diskursā norāda uz adjektīvisko pamatlietojumu un kādas uz lietojumu artikula funkcijā. Raksta autore ir nonākusi pie secinājuma, ka galvenā pazīme, kas šķir abus lietojumus, ir reference uz tekstā minēto - adjektīviskajam lietojumam ir atrodama reference iepriekš runātajā vai rakstītajā, bet tīrajā artikula nozīmē lietotam norādāmajam vietniekvārdam šādas references nav. Šāds lietojums turklāt ir sarunvalodisks un neatbilst literārās valodas normām 


\subsection{Norādāmo vietniekvārdu adjektīvisks lietojums ar konkrētu referenci}

Norādāmie vietniekvārdi adjektīviskā lietojumā ar konkrētu referenci, kā jau minēts, nav uzskatāmi par sarunvalodiskiem - šāds lietojums atbilst norādāmo vietniekvārdu pamatfunkcijai.

Piemērā (8) ar norādāmo vietniekvārdu marḳēts vārdu salikums Ruotsisymbolit ja -brändit 'Zviedrijas simboli un zīmoli'. Lai arī ne vārds simboli, ne vārds zìmoli iepriekš tekstā nav minēti, ir uzskaitīta virkne priekšmetu un nosaukumu, kas saistās ar Zviedriju, līdz ar to norādāmais vietniekvārds palīdz piešķirt konkrētu referenci uz iepriekšējo tekstu.

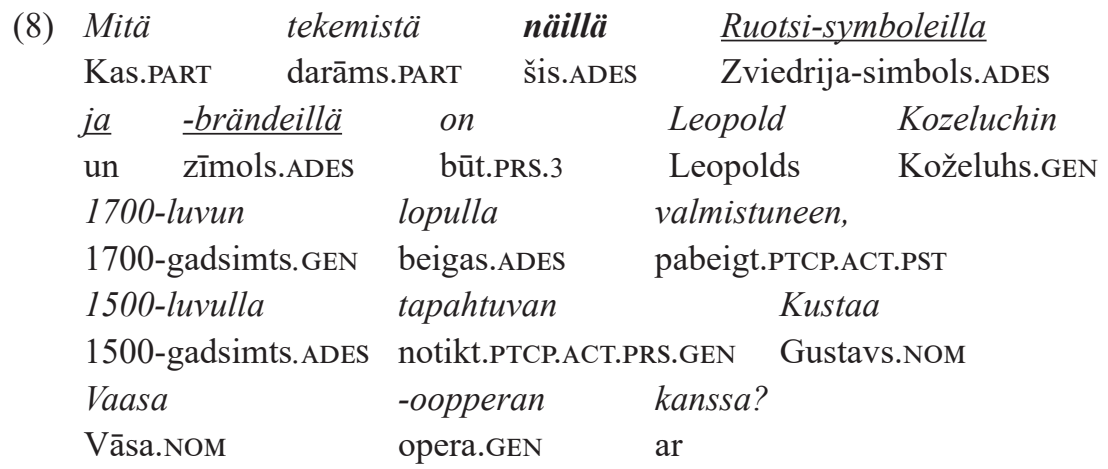

'Kāda šiem Zviedrijas simboliem un zīmoliem ir saistība ar Leopolda Koželuha 18. gadsimta beigās sarakstīto operu "Gustavs Vāsa", kuras darbība norisinās 16. gadsimtā?' (www.hs.fi)

Arī piemērā (9) norādāmais vietniekvārds adjektīva funkcijā ir lietots anaforiski, proti, tam ir konkrēta reference uz kaut ko tekstā iepriekš minētu, šajā gadījumā - uz Īzaku N̦ūtonu kā alķīmiķi:

(9) Newtonissa kirjoitetuissa elämänkerroissa tämä

N̦ūtons.INES sarakstīt.PTCP.PASS.PST.INES dzīvesstāsts.INES šis.NOM alkemistipuoli on yleensä vähemmä esillä. alḳimiķis_puse.NOM būt.PRS.3 parasti mazāk izstādīts. '[Par viṇu] sarakstītajos dzīvesstāstos šĩ N̦ūtona alḳīmiḳa šḳautne parasti ir mazāk parādīta.' (www.yle.fi)

Piemērā (10) norādāmajam vietniekvārdam savukārt ir deiktiska reference, proti, tas norāda nevis uz kaut ko, kas pieminēts teksta saturā, bet gan uz pašu tekstu kā kopumu:

$\begin{array}{lllll}\text { Ajattelin } & \text { täss ä } & \text { blogikirjoituksessa } & \text { valottaa } & \text { hieman } \\ \text { Domāt.PST.1 } & \text { šis.INES } & \text { blogs_ieraksts.INES } & \text { izgaismot.INF } & \text { mazliet } \\ \text { sitä, } & \text { miten } & \text { reportaasimatka } & \text { toteutetaan. } & \\ \text { tas.PART } & \mathrm{kā} & \text { reportāža_celojums.NOM } & \text { izpildīt.PRS.PASS } & \end{array}$

'Domāju šajā bloga ierakstā mazliet iezīmēt to, kā norisinās reportāžu braucieni.' (www.hs.fi) 
Piemēros (11) un (12) norādāmais vietniekvārds lietots adjektīviski gan kontekstuālā, gan deiktiskā nozīmē - piemērā (11) runa ir gan par dienu, kas minēta rakstā, gan dienu, ko piedzīvojis runātājs, savukārt piemērā (12) vārds paikka 'vieta' norāda gan uz vietu, kas aprakstīta, gan vietu, kurā atrodas runas situācijas dalībnieki.

(11) Se päivä oli

toiveiden täyttymys. tas.NOM diena.NOM būt.PST.3 cerība.GEN piepildījums.NOM 'Tā diena bija cerību piepildījums.' (www.hs.fi)

\section{(12) Tämä}

$\begin{array}{lll}\text { šis.NOM } & \text { vieta.NOM } & \text { būt.AUX.PRS.3 } \\ \text { minusta } & \text { jo } & \text { osan. } \\ \text { es.ELL } & \text { jau } & \text { daḷ.GEN }\end{array}$

\section{murhannut}

nogalināt.PTCP.ACT.PST.NOM

'ড̌̄̄ vieta ir jau nogalinājusi daḷu manis.' (www.yle.fi)

Arī preses tekstos latviešu valodā atrodami abējādi gadījumi. Piemēros (13) un (14) ar norādāmo vietniekvārdu tiek marķēti vārdi, kas ir vai nu pieminēti iepriekš tekstā, vai izprotami iepriekšējā kontekstā. Abos gadījumos ir skaidri redzams, ka norādāmais vietniekvārds piešķir konkrētu referenci, jo citādi var rasties šaubas par to, kāds jautājums īsti ir Ekonomikas ministrijas kompetencē un vai Ziemeḷkorejas režīms dižojas ar jebkuras nekonkrētas raḳetes iespējām.

(13) Taču šis jautājums faktiski ir EM kompetencēe. (www.diena.lv)

(14) Režīms dižojas, ka ar šo raketi Ziemeḷkorejai ir iespējas sasniegt mērk̦us. (www.diena.lv)

Piemērā (15) savukārt marķēts vārds spēle, kas ir gan pieminēts tekstā, gan ir paša teksta galvenā tēma. Līdz ar to vietniekvārds norāda, ka Porzinǵ̣is atklājis nevis jebkuras spēles rezultātu, bet gan konkrētās, tekstā aplūkotās.

(15) Šìs spēles rezultātu atklāja Porzinggis. (www.diena.lv)

Kā minējusi D. Nīiņa $(2013,441)$, gadījumos, kad ,vietniekvārds [tas, tāa] latviešu valodā tuvinās noteiktā artikula funkcijai”, tas ,var tikt lietots pārī ar vietniekvārdu šis, $\breve{s} \breve{\imath}$ '. Šāds lietojums atrodams arī preses tekstos, kā redzams piemērā (16). Šajā gadījumā lietojums uzskatāms par pamatotu un ir kategorizējams kā norādāmā vietniekvārda adjektīvisks lietojums ar konkrētu referenci, jo marķētais vārds tiek paskaidrots tālākā tekstā.

(16) Šis nebija tas gadījums, kad sarkanvīna skurbināti inteligences pārstāvji deklarēja, ka grāmata bijusi labāka par filmu. (www.diena.lv)

Vērtējot aplūkotos piemērus, ir skaidrs, ka adjektīva funkcijā lietoti norādāmie vietniekvārdi ar konkrētu referenci palīdz lasītājam škirt kontekstā pieminētos priekšmetus no citiem, līdz ar to tie palīdz gan sniegt nepieciešamo informāciju, gan arī izteikt saturu skaidrāk un kodolīgāk. 


\subsection{Norādāmo vietniekvārdu adjektīvsks lietojums bez konkrētas references}

Gadījumi, kad preses tekstos parādītos norādāmā vietniekvārda lietojums tīrā artikula funkcijā, proti, bez references uz iepriekšējo diskursu, ir visai reti. Lielākoties tie atrodami intervijās, kurās fiksēta diezgan spontāna runa. Daži piemēri atrodami gan somu, gan latviešu valodas tekstos. Pagaidām atrasto piemēru apjoms diemžēē nav tik liels, lai varētu spriest, vai kādā no valodām š̄i parādība ir sastopama biežāk.

(17) Tänään on

Šodien būt.PRS.3 tas.NOM skola.ILL reǵistrēšanās.NOM

Korte huomauttaa.

Korte.NOM pievērst uzmanību.PRS.3

'„Šodien ir tā reǵistrēšanās skolai,” Korte piezīmē.' (www.yle.fi)

Piemērā (17) reālijai kouluun ilmoittauttuminen 'reǵistrēšanās skolā' netiek pievienota konkrēta reference, līdz ar to ir lieki šo vārdu marḳēt ar norādāmo vietniekvārdu - to atmetot, doma nemainītos. Tāpat vērtējams arī piemērs (18):

(18) Tā kā mans atklājums notika tieši tajā brīdī, kad šis postmodernisms bija kaut kas jauns. (www.lsm.lv)

Tekstā minēts postmodernisms kā mākslas virziens, un tam nav pievienota konkrēta reference, kuras dēḷ to vajadzētu marķēt ar noteikto vietniekvārdu. Šajā gadījumā vietniekvārds artikula funkcijā visdrīzāk lietots aiz ieraduma (Mežale 2018, 198).

Piemērā (19) artikula funkcijā lietotais se 'tas, tā' ir vērtējams kā lieks, jo tas nepiešķir papildu nozīmi, kā arī nav attiecināms ne uz vienu tekstā iepriekš minētu priekšmetu. Iespējams, citētā persona ir vēlējusies uzsvērt konkrēto vārdu, tādējādi piešksirot tam lielāku nozīmi, taču, tā kā tekstā ir citēti tikai atsevišksi izteikumi, nevis visa saruna, tas nav droši nosakāms.

\begin{tabular}{|c|c|c|c|}
\hline $\begin{array}{l}\text { Olen } \\
\text { būt.PRs.1 }\end{array}$ & $\begin{array}{l}\text { saanut } \\
\text { dabūt.PTCP.ACT.PST.NOM }\end{array}$ & $\begin{array}{l}\text { sen } \\
\text { tas.ACC }\end{array}$ & $\begin{array}{l}\text { kuvan, } \\
\text { bilde.ACC }\end{array}$ \\
\hline se & on kunniapaikka. & & \\
\hline tas.NOM & goda vieta.NOM & & \\
\hline
\end{tabular}

Kā liecina raksta autores novērojumi, šāds izteikums somu valodā ir visai ierasts, tomēr biežāk vietniekvārds se 'tas, tā' tiek aizstāts ar iespaida radītāju, kā redzams piemērā (20):

(20)
Olen
saanut
äidiltä
kuvan,
būt.PRS.1
dabūt.PTCP.ACT.PST.NOM
mamma.ABL
bilde.ACC
että...
ka

'Mamma man ir radījusi iespaidu, ka...' (E. Mežales piemērs) 
Šajā gadījumā, kad paralēli pastāv divi varianti, būtu jāvērtēe, vai lietojuma biežums un ieradums būtu pietiekams iemesls, lai variantu ar norādāmo vietniekvārdu atzītu par normētu artikula lietojumu. Raksta autore tomēr sliecas domāt, ka šāds lietojums artikula nozīmē nav uzskatāms par normētu un obligātu (Mežale 2018, 199).

Interesants ir gadījums, kad vietniekvārds tas tiek lietots, tulkojot tekstu no svešvalodas, kuras gramatiskajā sistēmā pastāv artikuli, kā tas ir piemērā (21).

(21) Eirovīzijas dalībniece Dami Ima no Austrālijas ien̦ēma 2. vietu, bet Krievijas pārstāvis Sergejs Lazarevs ar dziesmu You Are the Only One (Tu esi tā vien̄̄gā), kuram bukmeikeri pirms konkursa prognozēja pārliecinošu uzvaru, ierindojās 3. vietā. (www.diena.lv)

Šajā gadījumā nav viennozīmīgi vērtējams tas, vai artikula funkcijā lietotais vietniekvārds patiešām ir neveiksmīgi kalkēts tulkojums no angḷu valodas. No vienas puses, dziesmas nosaukuma tulkotājs visdrīzāk ir vēlējies uzsvērt vārda vienīgā emocionālo slodzi. No otras puses, runājot par tulkojuma kvalitāti, jāteic, ka šajā gadījumā būtu labāk izvēlēties kādu latviešu valodā ierastāku frāzi, pat ja tas nebūtu burtisks tulkojums, piem., „Tu esi mana vienīgā” vai ,Tu esi viena vienīgā", kas neizmainītu teiktā jēgu. No aplūkotajiem piemēriem šis ir vienīgais, kad vietniekvārds artikula funkcijā izmantots tulkojuma avotvalodā esošā artikula dēḷ (Mežale 2018, 199). Tomēr novērojams, ka reizēm arī oriǵināltekstos parādās kalkēts artikula lietojums, kā tas redzams piemērā (22).

(22) Komponēdams tās ,, 80 minūtes,", loti ievingrināju roku. (www.diena.lv)

Šajā gadījumā pirms skaņdarba nosaukuma nemotivēti lietots vietniekvārds tas. Lietojums vērtējams kā aizguvums no angḷu valodas vai kādas citas artikulu valodas, jo nekādas citas motivācijas tā lietojumam nav (Mežale 2018, 199).

Līdzīgs ir nākamais piemērs:

$\begin{array}{lllll}\text { Näyttäisi } & \text { siltä, } & \text { että } & \text { palkka } & \text { ei } \\ \text { izskatīties.COND.PRS.3 } & \text { tas.ABL } & \text { ka } & \text { alga.NOM } & \text { NEG } \\ \text { ole } & \text { se } & \text { ykkösjuttu } & & \text { Y-sukupolvelle. } \\ \text { būt.PRS } & \text { tas.NOM } & \text { prioritāte_lieta.NOM } & \text { Y-paaudze.ALL } \\ \text { 'Izskatās, ka alga nav tā } & \text { Y paaudzes prioritāte.' (www.yle.fi) }\end{array}$

Lai gan šajā gadījumā teksts jau sākotnēji ir rakstīts somu valodā un nav tulkojums, teikumā izmantotā konstrukcija ir valodām ar artikuliem gramatiskajā sistēmā, kurās tādi vārdi kā galvenais, pirmais, pēdējais u. tml. tiek marķēti ar noteikto artikulu. Vietniekvārds artikula funkcijā visdrīzāk lietots ieraduma dēl kā ietekme no angḷu vai zviedru valodas (Mežale 2018, 199-200).

Kā pieminēts iepriekš, norādāmais vietniekvārds adjektīva funkcijā bez konkrētas references var tikt lietots arī kā emocionālās ekspresijas pastiprinātājs. Emocionālā pastiprinātāja funkcijā lietotu norādāmo vietniekvārdu identificēšanu apgrūtina tas, ka formāli tie atbilst norādāmā vietniekvārda adjektīviskam lietojumam bez konkrētas references, proti, noteiktā artikula funkcijā. Tomēr, analizējot piemērus, raksta autore ir nonākusi pie secinājuma, ka ir pazīmes, kas abus lietojumus šķir. Uz vietniekvārda kā emocionālā pastiprinātāja funkciju norāda: 
1) līdz ar vietniekvārdiem lietota emocionāli ekspresīvā leksika;

2) vietniekvārdu biežs atkārtojums īsā teksta fragmentā;

3) pastiprinājuma piedēkḷi somu valodā.

Minētās pazīmes atrodamas piemēros (24)-(28). Kā var redzēt, latviešu valodā vietniekvārdu biežs atkārtojums ir primārā pazīme, kamēr emocionāli ekspresīvās leksikas izmantojums ir sekundāra pazīme, kas tikai paspilgtina ekspresivitāti:

(24) Tas bija briedis, taču rakstniekos bija iedzìts mazvērtības komplekss - tu taču piederi pie tās nožēlojamās latviě̌u literatūras, kurā nekā nav [..]. Tā bija klaja netaisnība, un rakstnieki bija nedaudz nospiesti no tās sajūtas, ka atrodas tajā nelaimes dīkī. (www.diena.lv)

(25) „Billē” ir visas tās pretrunas, tā esence. (www.diena.lv)

(26) Taču ,iziešana ārpus no š̄̌s askētiskās nodarbes, no š̄̄s celles, kurā rakstnieks raksta, ir spilgts kontrasts [..]”. (www.diena.lv)

(27) Tajā ir visas š̄̌s parūkas, visa š̄ greznība, šis skaistums, kas sen aizgājis. (www.lsm.lv)

Interesanti, ka somu valodā raksta autore līdz šim ir atradusi tikai vienu piemēru, kurā norādāmais vietniekvārds ir lietots kā emocionālās ekspresijas pastiprinātājs:

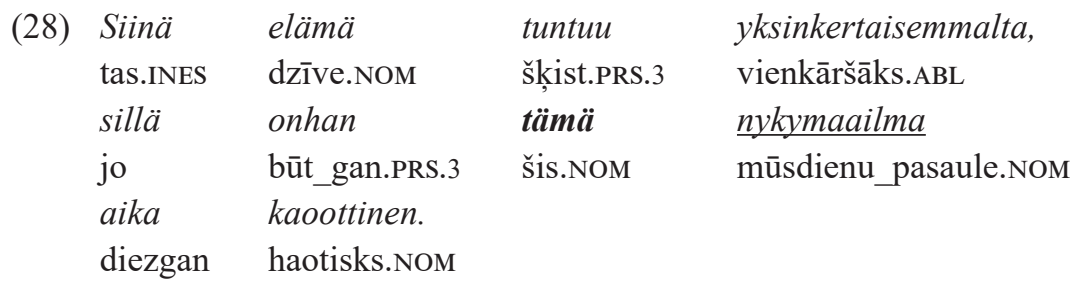

'Tajā dzīve škiet vienkāršāka, jo šī mūsdienu pasaule taču ir visai haotiska.' (www.yle.fi)

Piemērā (28) norādāmo vietniekvārdu tämä 'šis, šs’’ papildina pastiprinājuma piedēklis -han, kas pievienots darbības vārdam olla 'būt'. Kopā ar norādāmo vietniekvārdu tas piešķir teiktajam papildu ekspresiju.

Lai arī piemēros (24)-(28) norādāmais vietniekvārds tiek lietots adjektīviski bez konkrētas references, proti, marḳētie lietvārdi un lietvārdu frāzes nav tekstā iepriekš minēti, tie sniedz papildu informāciju un pilda papildu funkciju, proti, parāda runātāja attieksmi pret runas tematu. Līdz ar to šādi lietoti norādāmie vietniekvārdi nav uzskatāmi par tīriem artikuliem.

\section{Secinājumi}

Kopumā var secināt, ka norādāmajiem vietniekvārdiem artikula funkcija nereti tiek piešķirta sarunvalodā, taču gramatiskajā sistēmā ne latviešu, ne somu valodā par vietniekvārda gramatizēšanos, proti, kḷūšanu par artikulu, pagaidām nevar runāt. Faktu, ka somu valodniecības speciālistiem šajā jautājumā ir mazāk 
vienprātības nekā latviešu valodas pētniekiem, iespējams, skaidro noteiktības un nenoteiktības kategorijas latviešu un somu valodā, kā arī atšķirības šo kategoriju izteikšanā. Proti, somu valodā īpašības vārdiem nav noteikto galotņu, kas palīdzētu piešķirt noteiktību teikuma objektam, līdz ar to adjektīviski lietoti norādāmie vietniekvārdi it kā ieņem to vietu.

Ne latviešu, ne somu valodas gramatiskajā sistēmā artikuls nav iekḷauts, pirmkārt, tādēḷ, ka vēl nav noteikti gadījumi, kuros vietniekvārdu lietošana artikula funkcijā būtu obligāta, un, otrkārt, tādēḷ, ka norādāmie vietniekvārdi adjektīviskā lietojumā tomēr saglabā savu pamatfunkciju. Tā kā gadījumi, kad norādāmais vietniekvārds lietots adjektīviski ar konkrētu referenci, proti, atsaucoties uz tekstā iepriekš nosauktu lietu vai parādību, tiek šķirti no adjektīviski lietota norādāmā vietniekvārda bez konkrētas references, nav pamata uzskatīt, ka norādāmais vietniekvārds tuvākajā laikā varētu kḷūt par noteikto artikulu. Artikula funkcijā lietots norādāmais vietniekvārds nepieškiir markētajam vārdam nekādu referenci, līdz ar to ir uzskatāms par lieku.

Pagaidām gan nav izstrādāti kritēriji, pēc kuriem noteikt norādāmā vietniekvārda lietojuma artikula funkcijā nepieciešamību un/vai attaisnojamību valodās, kuru gramatiskajā sistēmā artikulu nav. Šeit jānem talkā Paolas Krismas (Paola Crisma 2011, 177-178) secinātais, ka valodās, kurās artikuli attīstījušies, ir divi to lietošanas pamatnosacījumi:

1) lietvārds vai lietvārda frāze tiek uzskatīta par nenoteiktu, ja vien tā nav marḳēta kā neapšaubāmi noteikta (Crisma 2011, 177). Kā jau minēts iepriekš, šāds nosacījums somu un latviešu valodā nedarbojas, jo pastāv citi valodas līdzekḷi, ar kuru palīdzību izteikt noteiktību. Šis nosacījums varētu darboties tikai gadījumos, kad noteiktību nebūtu iespējams izteikt ar citiem līdzekḷiem, kā vien noteiktības norādītāju;

2) lietvārds vai lietvārda frāze tiek marḳēta ar noteikto artikulu gadījumā, ja tas ir subjekts vai objekts, bet ne gadījumā, ja tas ir predikāts (Crisma 2011, 177-178). Šo nosacījumu varētu dal̦ēji attiecināt uz somu valodu, jo, kā jau minēts, somu valodā nav daudz tādu valodas līdzekḷu, ar kuru palīdzību varētu kā noteiktu marḳēt teikuma subjektu. Tomēr objekta noteiktības izteikšanai pastāv tādi līdzekḷi kā partitīva un ǵenitīva nenoteiktības un noteiktības opozīcija. Latviešu valodā šāds kritērijs nedarbotos, jo, izmantojot īpašības vārdus ar noteiktajām galotnēm, iespējams kā noteiktu marķēt gan teikuma subjektu, gan objektu.

Aplūkojot analizētos piemērus, var izdarīt secinājumu, ka lielākā daḷa norādāmo vietniekvārdu lietojuma funkciju abās valodās sakrīt. Tomēr ir daži izṇēmumi, piem., norādāmie vietniekvārdi emocionālā pastiprinātaja funkcijā lielākoties ir atrodami preses tekstos latviešu valodā, savukārt vienīgais piemērs ar norādāmā vietniekvārda substantīvisku lietojumu, runājot par personu, atrasts presē somu valodā.

Lai arī noteiktā artikula nav ne latviešu, ne somu valodas gramatiskajā sistēmā, abās valodās ir samērā liels skaits gadījumu, kad norādāmais vietniekvārds lietots adjektīviski. Tomēr vien maza daļa no tiem ir gadījumi, kuros norādāmais vietniekvārds būtu lietots noteiktā artikula funkcijā, proti, bez konkrētas references, 
turklāt nevienā no aplūkotajiem gadījumiem šāds lietojums nebūtu uzskatāms par obligātu - atmetot norādāmos vietniekvārdus, teksta jēga nemainītos.

Vērtējot diskursa kontekstā izsecināmo norādāmo vietniekvārdu lietojuma motivāciju visos piemēros kopumā, raksta autore šķir trīs adjektīviski lietotu vietniekvārdu grupas:

1) vietniekvārdi, kas lietoti motivēti un norāda uz kādu tekstā iepriekš minētu lietu vai parādību, piešķirot tai konkrētu referenci, proti, norādāmie vietniekvārdi adjektīviskā lietojumā, kas būtībā saglabā savu pamatfunkciju;

2) vietniekvārdi, kas lietoti bez konkrētas references, visbiežāk ieraduma dēl vai citu valodu iespaidā;

3) vietniekvārdi, kas uzsver runātāja vai teksta autora attieksmi pret konkrēto parādību un paspilgtina teiktā emocionālo ekspresiju;

Latviešu valodā norādāmie vietniekvārdi tas, tā un šis, šs adjektīiviskā lietojumā bez konkrētas references tiek lietoti galvenokārt intervijās, kurās tie fiksēti kā intervējamā runas daḷa. Arī somu valodā šī pazīme novērojama lielākoties intervijās, turklāt visbiežāk tādos tekstos, kuros bagātīgi sastopamas arī citas sarunvalodas pazīmes, piem., slengismi.

Citi norādāmo vietniekvārdu lietojumi, kā substantīviskais lietojums un adjektīviskais lietojums ar konkrētu referenci, sastopami dažādos preses tekstu žanros, kā ziṇu teksti, viedokḷu raksti, intervijas u.c. Tā, piem., norādāmo vietniekvārdu substantīvisks lietojums ir atrodams gandrīz jebkurā no darba gaitā aplūkotajiem tekstiem, un tam lielākoties nav sarunvalodiskas nokrāsas, izṇemot gadījumus, kad norādāmie vietniekvārdi lietoti, norādot uz personu. Arī norādāmie vietniekvārdi adjektīviskā lietojumā ar konkrētu referenci ir atrodami daudzos tekstos, un tie nepiešķir tekstam sarunvalodisku ekspresiju.

Kopumā vietniekvārdu lietojums adjektīva nozīmē latviešu un somu preses tekstos neatšķiras, tāpēc autore ierosina, ka arī somu valodā būtu derīgi dažādos norādāmā vietniekvārda lietojumus adjektīva funkcijā skatīt škirti, kas līdz šim nav darīts.

Pētījums par norādāmajiem vietniekvārdiem būtu turpināms, apgūstot apjomīgāku piemēru korpusu. Tādējādi būtu iespējams izprast, vai abi pieḷaujamie norādāmo vietniekvārdu adjektīviskie lietojumi somu un latviešu valodā ir sastopami vienlīdz bieži, kā arī konstatēt, vai tiešām parādības, kas līdz šim novērotas tikai somu vai tikai latviešu valodā, nav sastopamas otrā valodā.

\section{Saīsinājumi}

$\begin{array}{ll}1,3 & \text { persona } \\ \text { ABL } & \text { ablatīvs } \\ \text { ACC } & \text { akuzatīvs } \\ \text { ACT } & \text { aktīvs } \\ \text { ADES } & \text { adesīvs } \\ \text { ALL } & \text { allatīvs } \\ \text { AUX } & \text { palīgdarbības vārds }\end{array}$




$\begin{array}{ll}\text { COND } & \text { vēlējuma izteiksme } \\ \text { ELL } & \text { elatīvs } \\ \text { ESS } & \text { esīvs } \\ \text { GEN } & \text { ǵenitīvs } \\ \text { ILL } & \text { illatīvs } \\ \text { INES } & \text { inesīvs } \\ \text { INF } & \text { nenoteiksme } \\ \text { IRR } & \text { neregulārs } \\ \text { NEG } & \text { noliegums } \\ \text { NOM } & \text { nominatīvs } \\ \text { PART } & \text { partitīvs } \\ \text { PASS } & \text { pasīvs } \\ \text { PRS } & \text { tagadne } \\ \text { PST } & \text { pagātne } \\ \text { PTCP } & \text { divdabis }\end{array}$

\section{Avoti}

1. www.diena.lv (Latvijas dienas laikraksta „Diena” elektroniskā versija)

2. www.hs.fi (Somijas dienas laikraksta Helsingin sanomat elektroniskā versija)

3. www.lsm.lv (Latvijas sabiedrisko mediju ziņu portāls)

4. www.yle.fi (Somijas sabiedrisko mediju Yleisradio Oy ziṇu portāls)

\section{Literatūra}

1. Barbare, Dzidra. 2002. Vietniekvārds. Latviešu literārās valodas morfologiskās sistēmas attīstība: lokāmās vārdšķiras. Pokrotniece, Kornēlija (red.). Rīga: LU Latviešu valodas institūts, 309-408.

2. Bhat, Darbhe Narayana Shankara. 2004. Pronouns. Oxford: Oxford University Press.

3. Breņķe, Ieva. 2013. Noteiktības un nenoteiktības kategorijas teorētiskie aspekti. Vārds un tā pētī̌sanas aspekti: rakstu krājums. 17 (I). Liepāja: LiePA, 15-23.

4. Chesterman, Andrew. 1991. On Definiteness: A Study with Special Reference to English and Finnish. Cambridge: Cambridge University Press.

5. Crisma, Paola. 2011. The emergence of the definite article in English. A contactinduced change? The Noun Phrase in Romance and Germanic. Structure, Variation, and Change. Sleeman, Petra, Perridon, Harry (eds.). Amsterdam/Philadelphia: John Benjamins Publishing Company, 175-192.

6. Hakulinen, Auli et al. 2004. Ison suomen kieliopin verkkoversio. Helsinki: Suomalaisen Kirjallisuuden Seura. Pieejams: http://scripta.kotus.fi/visk/sisallys. $\mathrm{php} p \mathrm{p}=15$.

7. Heine, Bernd, Kuteva, Tania. 2004. World Lexicon of Grammaticalization. Cambridge: Cambridge University Press.

8. Kalme, Vilma, Smiltniece, Gunta. 2001. Latviešu literārās valodas vārddarināšana un morfologija. Lokāmās vārdšķiras: mācību grāmata. Liepāja: LiePA.

9. Kalnača, Andra. 2011a. Morfologijas stilistika. Rīga: LU Akadēmiskais apgāds. 
10. Kalnača, Andra. 2011b. Norādāmo vietniekvārdu lietojums plašsaziṇas līdzekḷu tekstos. Valodas prakse: vērojumi un ieteikumi. 6. Rīga: Latviešu valodas aǵentūra, 33-40.

11. Kalnača, Andra. 2013. Morfologija. Latviešu valoda. Veisbergs, Andrejs (red.). Rīga: LU Akadēmiskais apgāds, 45-108.

12. Lappalainen, Hanna. 2010. Se ja hän puhutussa kielessä. Kielikello. 4/2010. Pieejams: http://www.kielikello.fi/index.php?mid=2\&pid=11\&aid=2340.

13. Larjavaara, Matti. 2001a. Määräinan artikkeli - suomessa? Kielikello. 4/2001. Pieejams: http://www.kielikello.fi/index.php?mid=2\&pid=11\&aid=1298.

14. Larjavaara, Matti. 2001b. Tämä, tuo vai se? Kielikello. 4/2001. Pieejams: http:// www.kielikello.fi/index.php?mid=2\&pid=11\&aid=1296.

15. Laury, Ritva. 1997. Demonstratives in Interaction: The Emergence of a Definite Article in Finnish. Amsterdam/Philadeplhia: John Benjamins Publishing Company.

16. Lyons, Christopher. 1999. Definiteness. Cambridge: Cambridge University Press.

17. Mežale, Emīlija. 2018. Norādāmie vietniekvārdi noteiktā artikula funkcijā latviešu un somu preses tiešsaistes izdevumos: pragmatiskā pieeja. Valoda: nozīme un forma. 9. Gramatika un pragmatika. Kalnača, Andra, Lokmane, Ilze (red.). Rīga: LU Akadēmiskais apgāds, 191-202.

18. Nītiņa, Daina. 2013. Vietniekvārds (pronomens). Latviešu valodas gramatika. Nītiņa, Daina, Grigorjevs, Juris (red.). Rīga: LU Latviešu valodas institūts, 428-455.

19. Ozola, Ārija. 2006. „Liekais” tas ne vienmēr ir lieks. Valodas prakse: vērojumi un ieteikumi. 2. Rīga: LU Akadēmiskais apgāds, 84-87.

20. Ozols, Arturs 1965. Veclatviešu rakstu valoda. Rīga: Liesma.

21. Paegle, Dzintra 2003. Latviešu literārās valodas morfologija. I daḷa. Rīga: Zinātne.

22. Tiittula, Liisa, Nuolijärvi, Pirkko. 2013. Puheen illuusio suomalaisessa kaunokirjallisuudessa. Helsinki: Suomalaisen Kirjallisuuden Seura.

\section{Summary}

The article provides an insight into demonstrative pronouns in Latvian and Finnish online press. The emphasis is put on the adjectival use of demonstrative pronouns, including pronouns used as definite articles and emotional markers. An insight into substantival use of demonstrative pronouns is also given. In the first section, the substantival use of demonstrative pronouns is studied, by analysing cases with reference to objects as well as cases with reference to persons, which are inherent to colloquial language. In the second section, the adjectival use of demonstrative pronouns is studied. Cases with and without particular reference in the text are analysed. Examples from press texts illustrate the theoretical material. As a result, three categories of adjectivally used demonstrative pronouns are distinguished. In two of those cases the use of demonstrative pronouns can be considered close to the use of definite article. Acquired results will be used for in-depth future studies and analysis of the use of demonstrative pronouns as definite articles.

Keywords: demonstrative pronouns; definite article; press language; Latvian language; Finnish language. 